\title{
Serum NGAL and copeptin levels as predictors of acute kidney injury in asphyxiated neonates
}

\author{
Małgorzata Baumert ${ }^{1} \cdot$ Piotr Surmiak $^{1}$ (D) $\cdot$ Andrzej Więcek $^{2} \cdot$ Zofia Walencka $^{1}$
}

Received: 24 March 2016/Accepted: 4 August 2016/Published online: 2 September 2016

(c) The Author(s) 2016. This article is published with open access at Springerlink.com

\begin{abstract}
Background Acute kidney injury (AKI) is the most common complication of perinatal asphyxia. Recent research indicates that serum neutrophil gelatinase-associated lipocalin (NGAL) is an early marker for AKI, but there are the lacks of data about its use in term neonates with perinatal asphyxia. Methods A prospective cohort study was conducted on 43 term neonates. Umbilical cord blood and $24 \mathrm{~h}$ after birth serum NGAL, copeptin, creatinine, and molality were measured in all asphyxiated and controls neonates.

Results During the study period, 8 of asphyxiated nenates (18.6\%) suffered from AKI, while 35 newborns have no signs of AKI and 30 healthy infants. We did not observe any differences in creatinine and copeptin levels, as well as serum osmolality in all three investigated groups (AKI, noAKI, and controls) in cord blood, and $24 \mathrm{~h}$ after birth. Serum NGAL levels in umbilical cord blood were significantly higher in the AKI group $(174.3 \mathrm{ng} / \mathrm{mL})$ compared with noAKI $(88.5 \mathrm{ng} / \mathrm{mL}, p=0.01)$ and control groups $(28.5 \mathrm{ng} /$ $\mathrm{mL}, p<0.001$ ), and $24 \mathrm{~h}$ after birth (respectively, AKI $152.5 \mathrm{ng} / \mathrm{mL}$ vs no-AKI $74.9 \mathrm{ng} / \mathrm{mL}, p=0.02$ vs controls $39.1 \mathrm{ng} / \mathrm{mL}, p<0.001)$. NGAL concentration showed a strong negative correlation to umbilical artery $\mathrm{pH}$ (Rho $=-0.42, p=0.04$ ), base excess (Rho $=-0.31$, $p=0.03)$, and Apgar score in 1st min $($ Rho $=-0.41$,
\end{abstract}

Piotr Surmiak

piotr.surmiak@sum.edu.pl

1 Department of Neonatology, School of Medicine in Katowice, Medical University of Silesia, Medyków 14 Street, 40-752 Katowice, Poland

2 Department of Nephrology, Endocrinology and Metabolic Diseases, School of Medicine in Katowice, Medical University of Silesia, Francuska 20/24 Street, 40-027 Katowice, Poland $p=0.02)$ and 5th min of life (Rho $=-0.20, p=0.001)$. ROC curve analysis demonstrated a good predictive value for NGAL levels ( $>140.7 \mathrm{ng} / \mathrm{mL}$ ) which allows to diagnose AKI in asphyxiated patients with $88.9 \%$ sensitivity $(95 \%$ CI 75-95\%) and $95.0 \%$ specificity (95\% CI 76-99\%).

Conclusion NGAL seems to be a promising marker, even in subclinical AKI in neonates, due to its high specificity, but copeptin did not meet expectations.

Keywords Asphyxia - Acute kidney injury - LCN2 protein - Copeptins · Osmolality

\section{Introduction}

Acute kidney injury (AKI) is a complex disorder with clinical manifestations ranging from mild dysfunction to complete anuric kidney failure. Renal failure is characterized by increased serum levels of creatinine and nitrogenous waste products, decreased in glomerular filtration rate and imbalance in water and electrolyte homeostasis [1]. Diagnosis of AKI in neonates is difficult as many of them have non-oliguric renal failure, especially in premature infants [2]. Moreover, serum creatinine concentration during the first few days after birth reflects the mother's and not the infant's kidney function [3].

There are many reasons for development of AKI in newborns. Renal failure may have a prenatal onset in congenital disease, especially in genetic diseases, and in the postnatal period maybe related to hypoxic ischemic injury, intubation at birth, respiratory distress syndrome, toxic insults, etc. [1, 4]. Some authors reported the high occurence of AKI in neonates with perinatal asphyxia [5, 6]. In a study by Abu-Haweleh, perinatal asphyxia, with a prevalence of $42 \%$, was the most common predisposing factor for AKI in neonates and thus, associated with high mortality [7]. As 
neonates, with AKI, are at risk for developing chronic kidney disease and hypertension in the adult life, we search for novel markers that can improve the diagnosis of AKI within the first hours of an insult allowing the implementation of an effective prophylactic actions and/or treatment.

One of these novel biomarkers of AKI is neutrophil gelatinase-associated lipocalin (NGAL). It is known that serum and urinary levels of NGAL are elevated in neonates with AKI after cardiac surgery [8], and in a critically ill pediatric population [9].

In our previous studies, we demonstrated that NGAL can be a valuable biomarker of acute incidence of perinatal asphyxia in neonates $[10,11]$. Hence, we want to test our hypothesis by demonstrating that elevated serum NGAL concentration is also an invaluable marker of AKI resulting from hypoxia.Moreover, we would also like to determine whether copeptin plays an important role in the evaluation of AKI. Copeptin is released in an equimolar ratio to vasopressin (AVP); however, it is more stable in circulation and easy to measure. Serum copeptin levels have been found to closely resemble the production of AVP, which is strongly related to serum osmolality [12]. Serum copeptin levels are increased in response to increased osmolality and dehydratation [13]. Some authors noticed that serum copeptin concentration was strongly related to factors associated with perinatal stress, such as asphyxia [14].

\section{Material}

Among 1,673 infants, born at the University Hospital in Katowice, Poland between January 2012 to May 2014, 43 term neonates were enrolled in a prospective study, after obtaining informed written consent from their parents. This study was approved by the Human Ethics Committee of the Medical University of Silesia. The collection of umbilical cord blood and blood samples $24 \mathrm{~h}$ after birth was required for this research.

Indicators of acute perinatal asphyxia included: the presence of a hypoxic event immediately prior or during delivery, history of fetal distress (bradycardia, late decelerations), metabolic acidosis (base deficit $\geq-16 \mathrm{mmol} / \mathrm{l}$ ) in the arterial umbilical cord blood, and $\mathrm{pH} \leq 7.0$.

Categorization of the enrolled asphyxiated neonates into asphyxia subgroups (AKI, no-AKI) was based on the Acute Kidney Injury Network (AKIN) criteria, as persistently increased serum creatinine $(>1.5 \mathrm{mg} / \mathrm{dL})$ for at least $24 \mathrm{~h}$ or rising values $>0.3 \mathrm{mg} / \mathrm{dL}$ from the baseline [15].

Thirty apparently healthy neonates of comparable gestational age born after an uncomplicated pregnancy and labor comprised the control group.

In our study, we excluded preterm neonates, with congenital abnormalities or chromosomal anomalies, newborns of mothers suffering from diabetes mellitus, hypertension, pre-eclampsia, and children of multiple pregnancies and metabolic disorders, and with evidence of congenital infections, as well as those that were born to mothers with clinical chorioamnionitis.

Patient care and monitoring were performed as part of the hospital's standard protocol. Neonates after the incidence of perinatal asphyxia were transferred to NICU, and acid-base balance was obtained $1 \mathrm{~h}$ after delivery. Needs for institution of hypothermia protocol was determined according to the recommendations from "Total Body Hypothermia for Perinatal Asphyxia (TOBY)" study group [16]; however, none of neonates from asphyxiated group met the criteria for whole body cooling.

\section{Methods}

Blood samples were drawn immediately after delivery of the child from the umbilical artery from the placental side of the cord and at $24 \mathrm{~h}$ after birth from the peripheral neonatal vessels. Blood samples were used for measurement of acid-base balance and serum NGAL, copeptin, creatinine, lactate levels as well as serum osmolality.After centrifugation, cord blood serum was frozen in tubes at $-80^{\circ} \mathrm{C}$. Serum copeptin concentration was determined using the immunoluminometric assay (Brahms CT-pro AVP LIA, Brahms GmbH, Hennigsdorf, Germany). The detection limit of the assay was $0.4 \mathrm{pmol} / \mathrm{L}$.

Serum NGAL concentration was determined using the sandwich enzyme immunoassay for the quantitative measurement of human lipocalin-2 (BioVendor- Labolatorni medicina a.s. Brno, Czech Republic). The detection limit of the assay was $0.02 \mathrm{ng} / \mathrm{mL}$. Blood gas analyses were established using a model Rapidlab 865 Blood Gas Analyzer (Siemens Medical Solutions Diagnostics, Bad Nauheim, Germany). Serum creatinine concentration was measured by a kinetic colorimetric Jaffe method (Modular P Analyzer; Roche Almere, the Netherlands). Serum osmolality was determined using a cryoscopic method establishing its freezing temperature with the use of the Vapor Pressure Osmometer 5520.

\section{Statistical analysis}

Continuous variables among the groups were compared using the Kruskal-Wallis and Mann-Whitney $U$ tests, while categorical variables were compared using Fisher's exact or Levene's tests. Quantitative variables were presented as mean or median and $95 \%$ confidence intervals, whereas qualitative variables were shown as percentages. Spearman correlation coefficients were calculated between NGAL, copeptin levels, and clinical variables. We also 
performed ROC curve analysis to determine the cutoff values of biochemical parameters as diagnostic markers of acute kidney injury in asphyxiated neonates. Statistical analysis was performed using standard procedures available in STATISTICA 10 (Statsoft Polska Inc.) and MedCalc Software Version 12.7.4. Statistical inferences were based on the level of significance $p<0.05$.

\section{Result}

During the study period, 43 neonates were born asphyxiated- 8 of them (18.6\%) developed AKI stage 1 based on serum creatinine AKIN criteria, while 35 newborns did not meet diagnostic criteria for AKI. Renal replacement therapy was not required. During the hospitalization, we observed in neonates with AKI creatinine levels normalization average on 3rd day of life.

The demographic and clinical characteristics of the studied neonates are listed in Table 1. There were no significant differences in these groups, except for the Apgar score $(p<0.001)$.
There were also no significant differences in serum copeptin levels and serum osmolality in all three groups (AKI, no-AKI, and controls) in cord blood, and $24 \mathrm{~h}$ after birth, as shown in Table 2. There were also no differences in serum creatinine in umbilical cord blood and after $24 \mathrm{~h}$ in our population arranged by gestational age and birth weight, shown in Table 3.

Although median serum copeptin concentrations were elevated within the AKI group $(660.1 \mathrm{pg} / \mathrm{mL})$ as compared with no-AKI $(520.8 \mathrm{pg} / \mathrm{mL})$ and controls $(566.7 \mathrm{pg} / \mathrm{mL})$, these differences were not significant $(p=0.32)$. No differences were observed between umbilical serum osmolality in all three investigated groups (AKI $286.4 \mathrm{mmol} / \mathrm{kg} \mathrm{H}_{2} \mathrm{O}$, noAKI $284.1 \mathrm{mmol} / \mathrm{kg} \mathrm{H}_{2} \mathrm{O}$ vs controls $284.1 \mathrm{mmol} / \mathrm{kg} \mathrm{H}_{2} \mathrm{O}$, $p=0.32$, respectively), and $24 \mathrm{~h}$ after birth (AKI $283.1 \mathrm{mmol} / \mathrm{kg} \mathrm{H} \mathrm{H}_{2} \mathrm{O}$, no-AKI $284.1 \mathrm{mmol} / \mathrm{kg} \mathrm{H}_{2} \mathrm{O}$ vs controls $284.0 \mathrm{mmol} / \mathrm{kg} \mathrm{H}_{2} \mathrm{O}, p=0.51$, respectively)—Fig. 1 . However, we observed significant difference in serum osmolality between umbilical cord blood and venous blood in AKI group $(p=0.02)$.

The median serum NGAL levels in umbilical cord blood were significantly higher in the AKI group $(174.3 \mathrm{ng} / \mathrm{mL})$
Table 1 Demographic and perinatal characteristics of asphyxiated and control neonates

\begin{tabular}{lllc}
\hline Variable & Asphyxiated neonates $(n=43)$ & Control group $(n=30)$ & $p$ value \\
\hline Mother's age (years) & $27(25-31)$ & $28(24-31)$ & 0.48 \\
Cesarean section (\%) & 85 & 71 & 0.18 \\
Gender male/female (\%) & $54 / 46$ & $61 / 39$ & 0.58 \\
Weeks of gestation (weeks) & $37(36-37)$ & $38(37-39)$ & 0.11 \\
Apgar 1st min (pts) & $4(3-6)$ & $8(8,9)$ & $<0.001$ \\
Apgar 5th min (pts) & $6(5-7)$ & $9(8,9)$ & $<0.001$ \\
\hline
\end{tabular}

Results are presented as medians and (95\% confidence intervals) or percentages. $p$ value from KruskalWallis or Fisher's exact tests

Table 2 Serum levels of creatinine (mg/dL), copeptin $(\mathrm{pg} / \mathrm{mL})$, NGAL $(\mathrm{ng} / \mathrm{mL})$, and serum osmolality (mmol/kg $\left.\mathrm{H}_{2} \mathrm{O}\right)$ in cord blood and in serum after $24 \mathrm{~h}$ of life in asphyxiated (AKI and no-AKI) newborns and in the control group

\begin{tabular}{|c|c|c|c|c|c|c|}
\hline & Asphyxiated $n=43$ & Controls $n=30$ & $p$ value & AKI $n=8$ & No-AKI $n=35$ & $p$ value \\
\hline Umbilical creatinine $(\mathrm{mg} / \mathrm{dL})$ & $0.8(0.7-0.8)$ & $0.9(0.8-1.0)$ & 0.56 & $0.9(0.7-1.1)$ & $0.8(0.8-0.9)$ & 0.26 \\
\hline $\begin{array}{l}\text { Serum creatinine after } 24 \mathrm{~h} \\
(\mathrm{mg} / \mathrm{dL})\end{array}$ & $0.8(0.8-0.9)$ & $0.9(0.8-1.0)$ & 0.62 & $1.0(0.8-1.2)$ & $0.8(0.8-0.9)$ & 0.09 \\
\hline Umbilical NGAL (ng/mL) & $146.4(105.8-187.0)$ & $28.5(21.9-35.0)$ & $<0.001$ & $174.3(117.8-230.7)$ & $88.5(59.1-118.0)$ & $<0.001$ \\
\hline $\begin{array}{l}\text { Serum NGAL after } 24 \mathrm{~h}(\mathrm{ng} / \mathrm{f} \\
\mathrm{mL})\end{array}$ & $113.5(85.6-141.4)$ & $39.1(25.2-53.1)$ & 0.06 & $152.5(80.1-224.8)$ & $74.9(55.5-94.4)$ & $<0.001$ \\
\hline Umbilical copeptin (pg/mL) & $512.9(429.2-596.6)$ & $566.7(452.4-681.1)$ & 0.78 & $660.1(273.5-1026.6)$ & $520.8(456.3-585.4)$ & 0.32 \\
\hline $\begin{array}{l}\text { Serum copeptin after } 24 \mathrm{~h}(\mathrm{pg} / \\
\mathrm{mL})\end{array}$ & $468.6(396.7-540.5)$ & $429.1(342.8-515.5)$ & 0.41 & $439.9(310.3-569.5)$ & $455.1(394.8-515.3)$ & 0.51 \\
\hline $\begin{array}{l}\text { Umbilical serum osmolality } \\
\left(\mathrm{mmol} / \mathrm{kg} \mathrm{H}_{2} \mathrm{O}\right)\end{array}$ & $284.5(282.9-285.1)$ & $284.1(281.7-286.5)$ & 0.72 & $286.4(282.8-289.9)$ & $284.1(282.7-285.5)$ & 0.29 \\
\hline $\begin{array}{l}\text { Serum osmolality after } 24 \mathrm{~h} \\
\left(\mathrm{mmol} / \mathrm{kg} \mathrm{H}_{2} \mathrm{O}\right)\end{array}$ & $283.8(281.9-285.0)$ & $284.0(282.3-285.0)$ & 0.35 & $283.1(280.6-285.9)$ & $284.1(282.8-285.4)$ & 0.76 \\
\hline
\end{tabular}

Results are shown as medians and (95\% confidence intervals). $p$ value from Kruskal-Wallis and Levene's tests

$N G A L$ neutrophil gelatinase-associated lipocalin, $A K I$ acute kidney injury 
Table 3 Serum creatinine values in umbilical cord blood and after $24 \mathrm{~h}$ in our population arranged by gestational age and birth weight

\begin{tabular}{|c|c|c|c|c|c|c|}
\hline \multirow[t]{2}{*}{ Variable } & \multicolumn{2}{|l|}{ Gestational age } & \multirow[t]{2}{*}{$p$ value } & \multicolumn{2}{|l|}{ Birth weight } & \multirow[t]{2}{*}{$p$ value } \\
\hline & $37-38$ & $39-40$ & & $<2500 \mathrm{~g}$ & $>2500 \mathrm{~g}$ & \\
\hline \multicolumn{7}{|l|}{ Creatinine level (mg/dL) } \\
\hline Umbilical cord blood & $0.74(0.48-1.10)$ & $0.68(0.37-1.05)$ & 0.41 & $0.81(0.56-1.21)$ & $0.65(0.34-1.18)$ & 0.18 \\
\hline $24 \mathrm{~h}$ after & $0.68(0.36-1.25)$ & $0.75(0.44-1.15)$ & 0.36 & 0.78 (0.39-1.09) & $0.72(0.42-1.27)$ & 0.35 \\
\hline
\end{tabular}

Results are presented as median values and (minimum and maximum values). $p$ value from Mann-Whitney $U$ test
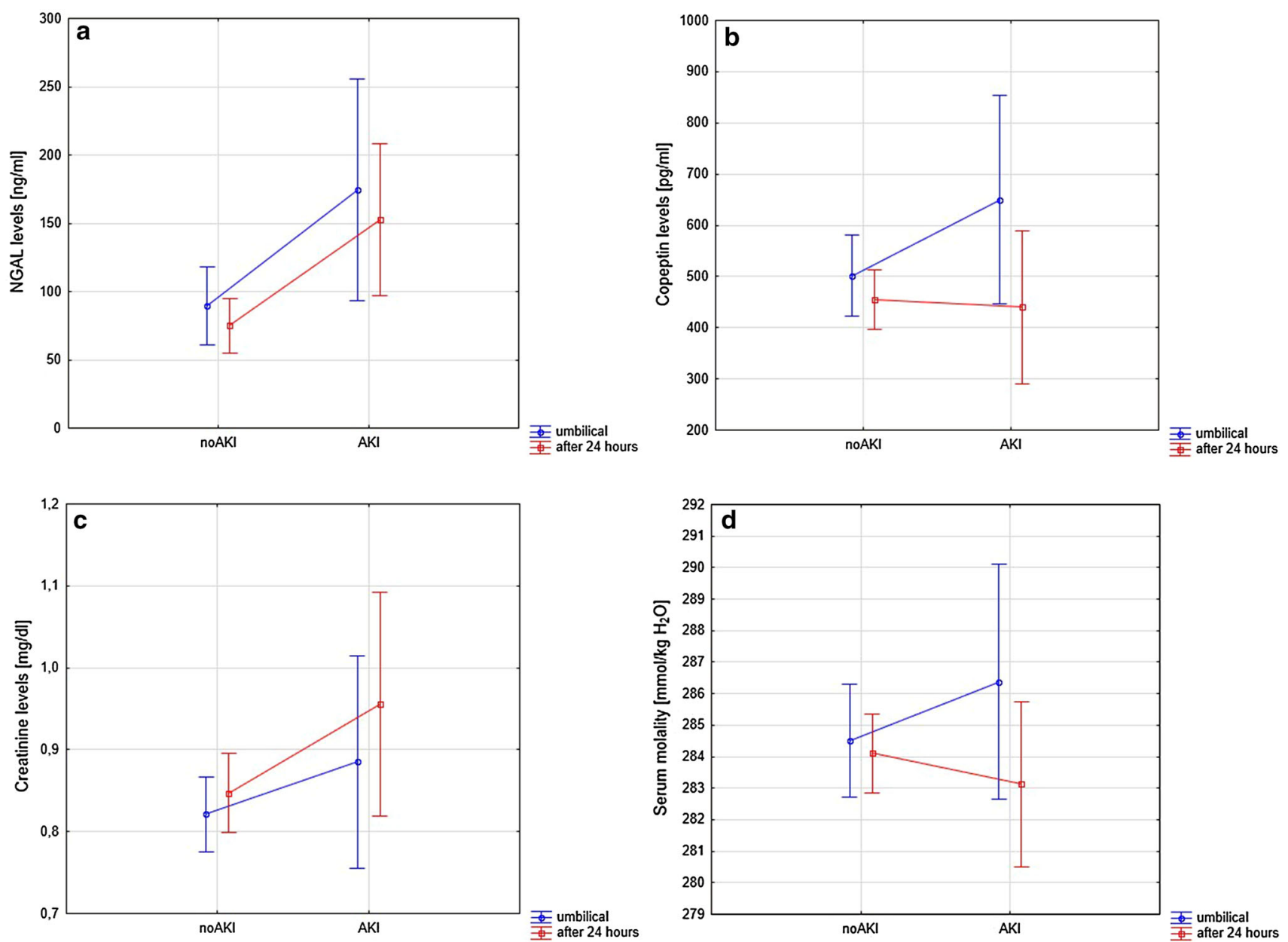

Fig. 1 NGAL, copeptin and creatinine levels, and serum osmolality in neonates with acute kidney injury (AKI) and newborns no-AKI in umbilical cord blood and $24 \mathrm{~h}$ after birth. Results are shown as

compared with no-AKI $(88.5 \mathrm{ng} / \mathrm{mL}, p=0.01)$ and control groups $(28.5 \mathrm{ng} / \mathrm{mL}, p<0.001)$, and $24 \mathrm{~h}$ after birth (respectively AKI $152.5 \mathrm{ng} / \mathrm{mL}$ vs no-AKI $74.9 \mathrm{ng} / \mathrm{mL}$, $p=0.02$ vs controls $39.1 \mathrm{ng} / \mathrm{mL}, p<0.001)$.

A strong negative correlation between NGAL cord blood concentration and umbilical arterial $\mathrm{pH}$ (Rho $=-0.42$, $p=0.04$ ), umbilical artery base excess (Rho $=-0.31$, $p=0.03$ ), and Apgar score in 1 st $\min (\mathrm{Rho}=-0.41$, $p=0.02)$ and 5th min of neonatal life (Rho $=-0.20$, $p=0.001)$.

medians and $95 \%$ confidence intervals. $N G A L$ neutrophil gelatinaseassociated lipocalin, $A K I$ acute kidney injury

ROC curve analysis demonstrated a critical level of NGAL in the umbilical cord blood $>67.5 \mathrm{ng} / \mathrm{mL}$, and this allows with $55.6 \%$ sensitivity (95\% CI 28-79\%) and $89.5 \%$ specificity (95\% CI 72-99 \%) to predict AKI in newborns. However, serum NGAL concentration, $24 \mathrm{~h}$ after birth, with a value $>140.7 \mathrm{ng} / \mathrm{mL}$ allows to diagnose AKI in asphyxiated patients with $88.9 \%$ sensitivity (95\% CI 75-95\%) and $95.0 \%$ specificity (95\% CI 76-99 \%) - Fig. 2. On the basis of the ROC curve analysis, a critical value was established for creatinine $>1.09 \mathrm{mg} / \mathrm{dL}$ in serum after $24 \mathrm{~h}$ in prediction of 


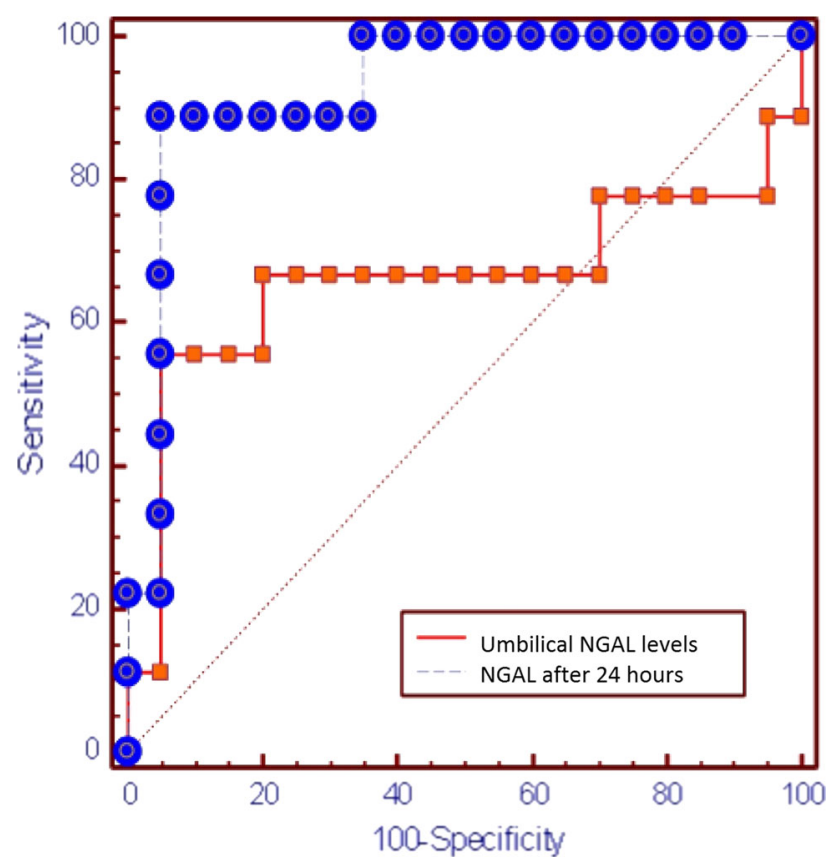

\begin{tabular}{|l|l|l|l|l|}
\hline & AUC & SE & $95 \%$ CI & $P$ value \\
\hline Umbilical NGAL level & 0.66 & 0.14 & $0.46-0.83$ & \multirow{2}{*}{0.01} \\
\hline NGAL after 24 hours & 0.93 & 0.05 & $0.77-0.99$ & \\
\hline
\end{tabular}

Fig. 2 Comparison of ROC curve analysis for prediction of AKI based on umbilical and 24-h NGAL levels in asphyxiated neonates. Comparison of ROC curves $(Z$ statistic $=2.14)$. AUC area under ROC curve, $S E$ standard error, $95 \%$ confidence interval for SE, NGAL neutrophil gelatinase-associated lipocalin, $A K I$ acute kidney injury

AKI in neonates with $71.4 \%$ sensitivity (95\%CI 65-85\%) and $78.8 \%$ specificity (95\%CI 63-90\%). However, area under ROC curve for umbilical creatinine level was not significant in prediction of AKI-Fig. 3.

\section{Discussion}

There are many different causes of acute renal failure in newborns [1]. In this study, we have focused on asphyxiated neonates. It is very important to recognize AKI as earlier as possible, hours after an insult occurred in comparison with days it may take serum creatinine to rise. However, validation of novel AKI biomarkers is impaired by the lack of a high quality, sensitive, and specific definition of AKI in neonates [17, 18]. In umbilical cord blood, normal creatinine values are unknown; however, there are some papers about creatinine values in neonates [19].

In our study, based on AKIN criteria in 8 neonates $(18.6 \%)$ of asphyxiated group diagnosed AKI and, similarly, on the faith of neonatal AKI KIDO classification, 8 neonates developed AKI stage 1 [20].
We investigated NGAL, copeptin, creatinine levels, and serum osmolality in neonates after acute perinatal asphyxia with and without acute kidney injury, and in healthy controls.

In our studies, we determined a significant difference in NGAL concentration both in umbilical cord and venous blood after $24 \mathrm{~h}$ of life between asphyxiated neonates with AKI and without AKI. The ROC curve analysis revealed that serum NGAL concentration, at a cut-off value of $140.7 \mathrm{mg} / \mathrm{dL}$ after $24 \mathrm{~h}$, could predict the development of AKI with high sensitivity (88.9\%) and specificity $(95.0 \%)$, while umbilical NGAL concentration characterized with low sensitivity (55.6\%), but high specificity $(89.5 \%)$ for the prediction of AKI. We suggest that the elevation of serum NGAL concentration after $24 \mathrm{~h}$ may play a pivotal role as an indicator of hemodynamic instability and serve as an important predictor of AKI. These data are in line with Raggal et al., who evaluated the NGAL concentration in asphyxiated neonates, $6 \mathrm{~h}$ after birth [21]. They demonstrated that a cut-off value of $157 \mathrm{ng} / \mathrm{mL}$ for serum NGAL could detect AKI in asphyxiated neonates with a sensitivity of $83.3 \%$ and specificity of $94.4 \%$.El-Farghali et al. showed that serum 


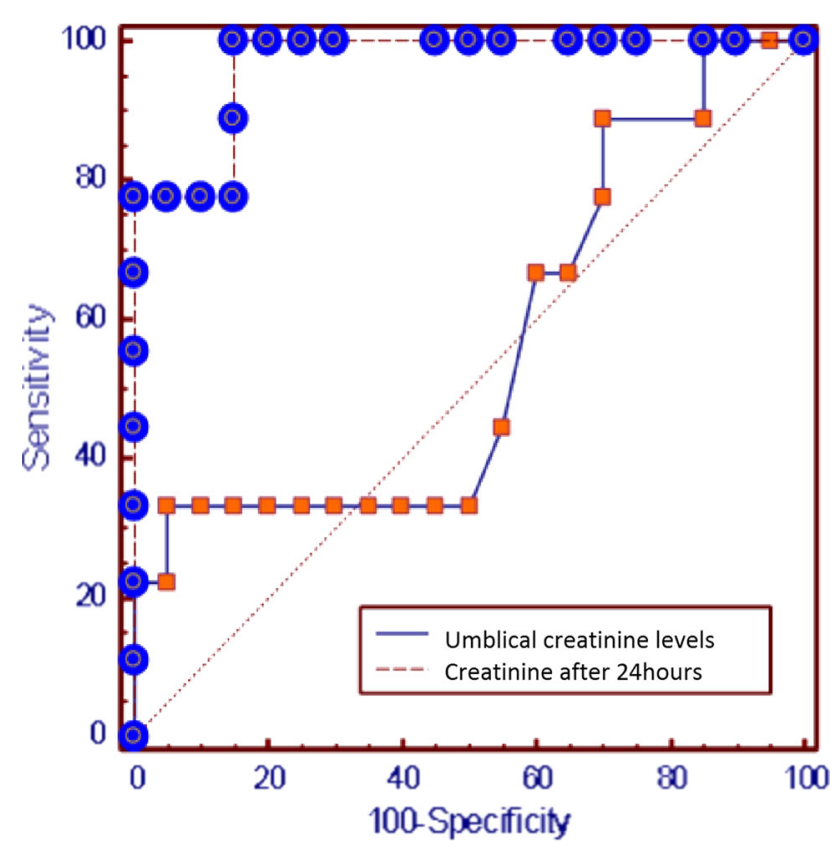

\begin{tabular}{|l|l|l|l|l|}
\hline & AUC & SE & $95 \%$ CI & $P$ value \\
\hline Umbilical creatinine level & 0.56 & 0.12 & $0.37-0.74$ & \multirow{2}{*}{$<0.001$} \\
\hline Creatinine after 24hours & 0.97 & 0.03 & $0.82-0.99$ &
\end{tabular}

Fig. 3 Comparison of ROC curve analysis for prediction of AKI based on umbilical and 24-h creatinine levels in asphyxiated neonates. Comparison of ROC curves $(Z$ statistic $=3.50)$. AUC area under ROC curve, SE standard error, $95 \%$ confidence interval for SE. NGAL neutrophil gelatinase-associated lipocalin, $A K I$ acute kidney injury

NGAL may also be serve as a clinically useful marker for early detection of AKI in critically ill neonates with sepsis [22]. The kidney responds to sepsis by upregulating NGAL production [23]. NGAL is one of the most strikingly upregulated genes and is an overexpressed protein in kidneys after ischemia [18].

Our findings indicate that copeptin cannot to be a predictor of early AKI. We did not observe any significant differences of serum copeptin levels in the groups with and without AKI, as well as the control group. Serum copeptin concentrations are characterized by a low sensitivity and specificity both in umbilical cord and venous blood after $24 \mathrm{~h}$. These data are, however, different than obtained by Schlapbach et al. [24]. The authors indicated the highest copeptin cord blood concentrations in neonates with perinatal asphyxia. They showed also that umbilical copeptin concentrations above $400 \mathrm{pmol} / \mathrm{l}$ had a high sensitivity and specificity for asphyxia.Copeptin pre-pro-vasopressin split product is also known as a marker of hydration status. Physiologically, when plasma osmolality is higher, copeptin levels are also increased [25]. Some authors demonstrated that in adults, during a hypertonic saline infusion and thirsting, there is a rise of serum osmolality which results in the increase in serum copeptin concentration [26].

In our study, serum copeptin concentration did not reveal significant diagnostic elements as a marker of osmolality. We have observed a significantly lower serum osmolality, in the umbilical cord than in venous blood after $24 \mathrm{~h}$, in neonates with AKI, but there were no significant differences in serum copeptin concentration. This could be as a result of possible subclinical kidney injury.

A non-significant decrease in copeptin concentration $24 \mathrm{~h}$ after birth has also been shown in the group with noAKI and control group, however, without any differences in serum osmolality. Due to the absence of differences in copeptin concentration in asphyxiated infants (AKI group and no-AKI) and healthy children, we suggest that copeptin cannot be a valuable, early marker of asphyxia and AKI in neonates. However, Benzing et al. disagree with this statement [27]. The authors postulated that cord blood copeptin is highly sensitive albeit minimally specific marker of fetal/neonatal distress.

Most likely the small number of investigated infants contributed to the difference between the results. 


\section{Conclusions}

Elevated serum NGAL concentration seems to be a promising, novel marker, even in subclinical forms of AKI in asphyxiated neonates, due to its high specificity, but copeptin did not meet such expectations.

\section{Compliance with ethical standards}

Conflict of interest The authors have declared that no conflict of interest exists.

Ethical approval All procedures performed in studies involving human participants were in accordance with the ethical standards of the institutional research committee at which the studies were conducted (Medical University of Silesia in Katowice no. KNW/022/ $\mathrm{KB} 1 / 35 / 12$ ) and with the 1964 Helsinki declaration and its later amendments or comparable ethical standards.

Informed consent Informed consent was obtained from all individual participants included in the study.

Open Access This article is distributed under the terms of the Creative Commons Attribution 4.0 International License (http://crea tivecommons.org/licenses/by/4.0/), which permits unrestricted use, distribution, and reproduction in any medium, provided you give appropriate credit to the original author(s) and the source, provide a link to the Creative Commons license, and indicate if changes were made.

\section{References}

1. Andreoli SP. Acute renal failure in the newborn. Semin Perinatol. 2004;28:112-3.

2. Gupta BD, Sharma P, Bagla J, et al. Renal failure in asphyxiaed neonates. Indian Pediatr. 2005;42:928-34.

3. Askenazi DJ, Ambalavanan N, Goldstein SL. Acute kidney injury in critically ill newborns: what do we know? What do we need to learn? Pediatr Nephrol. 2009;24:265-74.

4. Cataldi L, Leone R, Morett U, et al. Potential risk factors for the development of acute failure in preterm newborn infants: a casecontrol study. Arch Dis Child Fetal Neonatal Ed. 2005;90:514-9.

5. Portman RJ, Carter BS, Gaylord MS, et al. Predicting neonatal morbidity after perinatal asphyxia: a scoring system. Am J Obstet Gynecol. 1990;162:174-82.

6. Karlo J, Bhat BV, Koner BC, et al. Evaluation of renal function in term babies with perinatal asphyxia. Indian $\mathrm{J}$ Pediatr. 2014;81:243-7.

7. Abu-Haweleh AF. Acute renal failure in newborn: etiology and mortality rate in Jordan patients. Saudi J Kidney Dis Transplant. 1998;9:18-21.

8. Mishra J, Dent C, Tarabinshi R, et al. Neutrophil gelatinaseassociated lipocalin (NGAL) as a biomarker for acute renal injury after cardiac surgery. Lancet. 2005;365:1231-8.
9. Zappitelli M, Washbum KK, Arikan AA, et al. Urine neutrophil gelatinase-associated lipocalin is an early marker of acute kidney injury in critically ill children: a prospective cohort study. Crit Care. 2007;11:173.

10. Surmiak P, Baumert M, Fiala M, et al. Umbilical cord blood NGAL concentration as an early marker of perinatal asphyxia in neonates. Ginekol Pol. 2014;85:424-7.

11. Fiala M, Baumert M, Surmiak P, et al. Umbilical markers of perinatal hypoxia. Ginekol Pol. 2016;87:200-4.

12. Mellor AJ, Boos CJ, Ball S, et al. Copeptin and arginine vasopressin at high altitude: relationship to plasma osmolality and perceived exertion. Eur J Appl Physiol. 2015;115:91-8.

13. Morgenthaler NG, Struck J, Jochberger S, et al. Copeptin: clinical use of a new biomarker. Trends Endocrinol Metab. 2008;19:43-9.

14. Schlapbach LJ, Frey S, Bigier S, et al. Copeptin concentration in cord blood in infants with early-onset sepsis, chorioamnionitis and perinatal asphyxia. BMC Pediatr. 2011;11:38.

15. Mehta RL, Kellum JA, Shah SV, et al. Acute Kidney Injury Network: report of an initiative to improve outcomes in acute kidney injury. Crit Care. 2007;11:R31.

16. Azzopardi DV, Strohm B, Edwards AD, TOBY Study Group, et al. Moderate hypothermia to treat perinatal asphyxial encephalopathy. N Engl J Med. 2009;361:1349-58.

17. Sweetmann DU, Molloy EJ. Biomarkers of acute kidney injury in neonatal encephalopathy. Eur J Pediatr. 2013;172:305-16.

18. Mishra J, Ma Q, Prada A, et al. Identification of NGAL as a novel early urinary biomarker for ischemic renal injury. J Am Soc Nephrol. 2003;14:2534-43.

19. Bateman DA, Thomas W, Parravicini E, Polesana E, Locatelli C, Lorenz JM. Serum creatinine concentration in very-low-birthweight infants from birth to 34-36 wk postmenstrual age. Pediatr Res. 2015;77:696-702.

20. Selewski DT, Charlton JR, Jetton JG, Guillet R, Mhanna MJ, Askenazi DJ, Kent AL. Neonatal acute kidney injury. Pediatrics. 2015;136:e463-73.

21. Raggal NE, Khafagy SM, Mahmoud NH, et al. Serum NGAL as a marker of acute kidney injury in asphyxiated neonates. Indian Pediatr. 2013;50:459-62.

22. El-Farghali OG, El-Raggal NM, Mahmoud NH, et al. Serum neutrophil gelatinase- associated lipocalin as a predictor of acute kidney in cricitally-ill neonates. Pak J Biol Sci. 2012;15:231-7.

23. Parracini E, Nemerofsky SL, Michelson KA, et al. Urinary neutrophil gelatinase- associated lipocalin is a promising biomarker for late onset culture- positive sepsis in very low birth weight infants. Pediatr Res. 2010;67:636-40.

24. Meijer E, Bakker SJ, Halbesman N, et al. Copeptin, a surrogate marker of vasopressin, is associated with microalbuminuria in large population cohort. Kidney Int. 2010;77:29-36.

25. Szinnai G, Morgenthaler NG, Berneis K, et al. Changes in plasma copeptin, the C-terminal portion of arginine vasopressin during water deprivation and excess in healthy subjects. J Clin Endocrinol Metab. 2007;92:972-3978.

26. Benzing J, Wellmann S, Achini F, et al. Plasma copeptin in preterm infants: a highly sensitive marker of fetal and neonatal stress. J Clin Endocrinol Metab. 2011;96:E982-5. 